\title{
A comparison of the mechanical strength of three different suture techniques for intercostal thoracotomy closure - ex vivo study
}

\author{
Petar Kostešićc ${ }^{1}$ Mirta Vučković1, Janoš Kodvanj², Martin Šurjak², Dražen Vnuk ${ }^{1}$, \\ Nikica Daraboš ${ }^{3}$, and Dražen Matičić ${ }^{1 *}$ \\ ${ }^{1}$ Clinic for Surgery, Orthopaedics and Ophthalmology, Faculty of Veterinary Medicine, University of Zagreb, \\ Zagreb, Croatia \\ ${ }^{2}$ Faculty of Mechanical Engineering and Naval Architecture, University of Zagreb, Zagreb, Croatia \\ ${ }^{3}$ Clinic for Surgery, Cinical Hospital Center Zagreb, School of Medicine, University of Zagreb, Zagreb, Croatia
}

KOSTEŠIĆ, P., M. VUČKOVIĆ, J. KODVANJ, M. ŠURJAK, D. VNUK, N. DARABOŠ, D. MATIČIĆ: A comparison of the mechanical strength of three different suture techniques for intercostal thoracotomy closure - ex vivo study. Vet. arhiv 90, 637-642, 2020.

\section{ABSTRACT}

The transcostal closure technique of intercostal thoracotomy closure appears to be associated with less pain in the first 24 hours and could be an alternative to the standard circumcostal technique. The goal of this study was to compare the ex vivo biomechanical properties of three suture techniques for intercostal thoracotomy closure. Samples of porcine ribs were used for the research. A $10 \mathrm{~cm}$ incision was made in the intercostal space in each sample. The techniques compared were: simple circumcostal interrupted suturing, continuous circumcostal suturing, and interrupted transcostal suturing. During the testing in the machine, suture rupture or rib cracking occurred. If rib cracking occurred first, the testing was continued until the suture broke as well. In the first group, rib fracture occurrence was $60 \%$ and suture rupture was $40 \%$. In the second group, rib fracture occurrence was $55 \%$, while $45 \%$ of the samples failed by suture rupture. In the third group, rib fracture occurrence was $70 \%$, while suture rupture was $30 \%$. These data did not differ significantly between groups $(\mathrm{P}>0.05)$. Continuous circumcostal suturing took the least amount of time, and the most time-consuming technique was interrupted transcostal suturing. Simple circumcostal suturing used most material, and the least amount of material was used with continuous circumcostal suturing. The conclusion of this paper is that the continuous pattern suture has the same mechanical strength as the other two suture patterns, but it consumes the least time and material. Therefore, from a mechanical standpoint, we advise the use of continuous circumcostal suture for intercostal thoracotomy closure.

Key words: thoracotomy; closure; techniques; rib; strength; swine

\section{Introduction}

Thoracotomy is a surgical incision into the thoracic cavity, performed to gain access to the thoracic organs (ORTON, 2003). Several thoracotomy approaches are described in the

literature, and the correct choice of approach will determine the exposure of the operative field and the success of the operation. The best approach must be balanced between the least aggressive and the

\footnotetext{
*Corresponding author:

Dražen Matičić, DVM, MS, PhD, Clinic for Surgery, Orthopaedics and Ophtalmology, Faculty of Veterinary Medicine, University of Zagreb, Heinzelova 55, 10000 Zagreb, Croatia, Phone: +385 12390 384; Fax: +385 12441 390; E-mail: drmaticic@vef.hr
} 
safest exposure (MOSCARELLI and PUNJABI, 2011). Thoracic cavity surgery may be performed by intercostal (lateral) thoracotomy and median sternotomy. Intercostal thoracotomy should be considered when the definitive diagnosis is known and access to only one hemithorax is desired. An intercostal thoracotomy provides exposure of about one-third of the ipsilateral thoracic cavity and mediastinal structures, and exposure can be expanded by rib resection (RADLINSKY, 2012.). Lateral thoracotomy is preferred to median sternotomy as the latter technique is thought to be more difficult to perform, to be more painful and to have more complications, especially related to sternal osteomyelitis (MOORES et al., 2007).

Intercostal thoracotomy is used for lung lobectomy, surgical ligation of patent ductus arteriosus, division of the ligamentum arteriosum in animals with persistent right aortic arch, and access to the right heart, vena cava, azygos vein, oesophagus, pericardium and mediastinum (LOPEZ, 2007). The intercostal location varies, depending on the target structure to be operated.

The standard technique for intercostal thoracotomy closure is circumcostal interrupted suturing. The suture is passed around the cranial and caudal ribs and involves the intercostal nerve which is located on the caudal border of the caudal rib. The involvement of the intercostal nerve in the suture can produce severe postoperative pain. Continuous circumcostal suturing also produces postoperative pain related to the intercostal nerve in the suture involvement, but this suturing is a less time-consuming procedure. CERFOLIO et al. (2003) described a technical modification in the standard suturing of the intercostal space: performing the suture through the rib (transcostal or intracostal sutures).

Several studies have dealt with various aspects of surgical procedures and their relationship with postthoracotomy pain, which is occasionally severe and even incapacitating (CONZEMIUS et al., 1994). These studies have emphasized the importance of carefully avoiding injury to the intercostal nerves (GARCIA-TIRADO and RIEGER-REYES, 2012). The transcostal closure technique appears to be associated with less pain in the first 24 hours and could be an alternative to the standard circumcostal technique when closing an intercostal thoracotomy (ROONEY et al., 2004).

Although the transcostal suture technique provides the benefit of less pain, it inherently weakens the caudal rib when performed.

The goal of this research was to test and compare the ex vivo biomechanical properties, the time needed for suturing, and suture length used in three different suture techniques for intercostal thoracotomy closure (simple circumcostal interrupted suturing, continuous circumcostal suturing and interrupted transcostal suturing).

\section{Materials and methods}

Samples of swine ribs were used for thresearch. Three female landrace pigs, 6 months old, weighing from 20 to $30 \mathrm{~kg}$, were euthanized a day earlier, for reasons unrelated to thoracic wall pathology. Sample ribs from two contralateral sides were separated by cutting the sternum and the thoracic vertebra at the ventral and dorsal midline, using an oscillating saw. The rib samples, consisting of two adjacent ribs, were prepared by cutting in the intercostal spaces where suturing was not performed. The rib pairs used in the mechanical strength measurements consisted of ribs 4 and 5, 6 and 7,8 and 9, 10 and 11,12 and 13, from both sides of the thoracic wall.

Thirty rib pairs were obtained for the research. The samples were randomly divided into three groups, with 10 rib pair samples each. The samples were stored in a refrigerator overnight at $4{ }^{\circ} \mathrm{C}$. Prior to testing, the skin from the samples was removed. An incision through the intercostal muscles and pleura, $10 \mathrm{~cm}$ in length, was made in each sample. The samples were then randomly divided into three groups.

In the first group, the intercostal space was sutured with seven simple circumcostal interrupted sutures, using polygliconate monofilament absorbable suture material (Maxon TM 0, Covidien TM 8886 6261-61). The sutures were pre-positioned dorsalto-ventral, after which the sutures were tied ventralto-dorsal. The suture consisted of one surgical knot and four square knots. 
In the second group, the intercostal space was sutured using the same suture material, but with a continuous-pattern circumcostal suture. The suture was placed on the dorsal border of the incision, tied using one surgical knot and four square knots, continued distally with six circumcostal loops, and secured with one surgical knot and six square knots.

The third group had the intercostal spaces sutured with seven interrupted transcostal sutures, with the suture material passing through $1 \mathrm{~mm}$ predrilled holes in the caudal rib, and circumcostally around the cranial rib. The ribs were drilled with a $1 \mathrm{~mm} \mathrm{~K}$-wire and a battery drill. The sutures were pre-positioned dorsal-to-ventral, after which the sutures were tied ventral-to-dorsal. The knotting was performed in the same manner as in the first group.

During suturing, the elapsed time was recorded and the amount of suture material used was measured. The procedures were performed by two veterinary surgeons, each performing a similar number of sutures in each group.The research was conducted using a Messphysik Beta 50-5 computerised static testing machine. The machine is driven by an electric motor and achieves a maximum force of $50 \mathrm{kN}$. During the test, the machine was operated by the EDC25 control unit (Doli Elektronik Gmbh, Germany). The preset testing speed was $5 \mathrm{~mm} / \mathrm{min}$. The rib samples were fixed to the testing machine using a specially designed jig (Fig. 1), connected to the samples with two hooks on each side, taking care not to damage the sample or the sutures. During the testing, suture braking or rib cracking occurred. If rib cracking occurred first, the testing was continued until the suture broke as well.

Descriptive analysis was performed by use of statistical software (STATISTICA version 7.0 for Windows, Statsoft). The results are presented as means $\pm \mathrm{SD}$, unless otherwise stated. Differences were considered to be significant when $\mathrm{P}<0.05$. The Kruskal-Wallis test and ANOVA were used for analysis of the parameters force, shift, and suture length. The Fisher test was used to assess the relationship between the method used and test sample failure (rib fracture or suture material rupture).
Logistic regression analysis was used to assess the relationship between the method used and other variables. The Tukey test was used to determine the relationship between groups in the parameter suture length used.

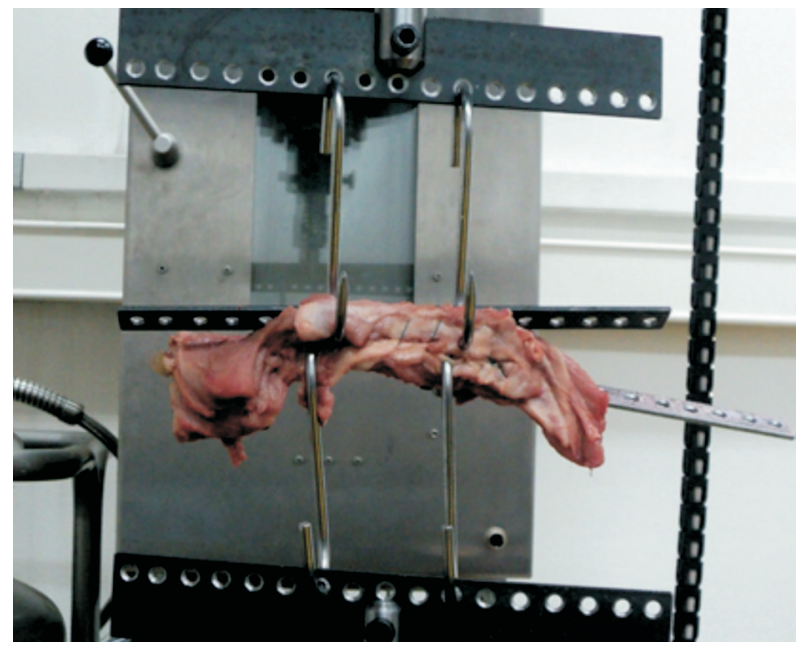

Fig. 1. The sutured rib sample fixed to the testing machine using a specially designed jig. The jig consists of two hooks on each side. The hooks are kept paralell with drilled spacers, allowing them to stay parallel, preventing them from sliding along the rib and causing an increase in stress. The lower and upper spacers are connected to the jaws of the testing machine.

\section{Results}

The test results were divided into three respective groups: simple circumcostal interrupted sutures, continuous-pattern circumcostal sutures and interrupted transcostal sutures. Each group included ten random samples. In the first group, $60 \%$ of the test samples failed by primary rib fracture, and $40 \%$ failed by suture rupture. In the second group, rib fracture occurred in 55\% of the test samples, while the remaining $45 \%$ of the test samples ended with suture rupture. In the third group, $70 \%$ of the test samples failed by rib fracture and $30 \%$ by suture rupture. All the rib fractures in this group occurred at one of the drilled holes. These data do not differ significantly between groups $(\mathrm{P}>0.05)$. Mean maximum force (the mean value of the maximum forces measured) during suture rupture was 101.71 $\mathrm{N}$ and mean maximum shift (the mean value of the maximum shifts in the samples measured) was $129.6 \mathrm{~mm}$. The results for all groups are shown 
in Table 1. Statistically, continuous circumcostal sutures have the same mechanical strength as the other two suture patterns, but they need less time and suture material, but on the other hand simple circumcostal suturing used the most material, and the most time-consuming technique was interrupted transcostal suturing. No inter-observer differences in the suturing time between the two surgeons were observed. No relationship was observed between the rib position and the results obtained.

Table 1. Maximum force, maximum shift, time and suture length used in all groups

\begin{tabular}{|c|c|c|c|c|}
\hline & Maximum force $(\mathrm{N})$ & Maximum shift $(\mathrm{cm})$ & Time $(\mathrm{s})$ & Used suture length $(\mathrm{cm})$ \\
\hline Group 1 & $548.1 \pm 61.7$ & $21.6 \pm 4.5$ & $497 \pm 145$ & $114.4 \pm 14.6$ \\
\hline Group 2 & $555.6 \pm 224.0$ & $20.8 \pm 5.4$ & $286 \pm 83^{*}$ & $62.3 \pm 3.5^{*}$ \\
\hline Group 3 & $537.3 \pm 147.4$ & $22.3 \pm 4.9$ & $629 \pm 208$ & $111.1 \pm 16.8$ \\
\hline
\end{tabular}

Group 1 - simple circumcostal interrupted sutures; Group 2 - continuous-pattern circumcostal suture; Group 3 - interrupted transcostal sutures); ${ }^{*}$ - differ significantly from other groups $(\mathrm{P}<0.05)$.

\section{Discussion}

The circumcostal interrupted suture technique is the standard technique for intercostal thoracotomy closure. The main drawback of this technique is the incorporation of the intercostal nerve into the suture, which causes severe post-thoracotomy pain (HOLTON et al., 1998).

Pain after intercostal thoracotomy has been associated with surgical trauma and neurovascular compression with the suture during closure, with ROONEY et al. (2004) reporting an especially high incidence of nerve entrapment using circumcostal closure techniques. On the basis of the lower pain scores observed with the transcostal suture technique, they suggest that this may be preferable to circumcostal closure techniques. Chronic postthoracotomy pain or neuralgia is defined by the Association for the Study of Pain as a "pain that recurs or persists along a thoracotomy scar for at least 2 months following the surgical procedure" (MERSKEY and BOGDUK, 1994). CERFOLIO et al. (2003) analyzed post-thoracotomy pain after using circumcostal and transcostal suture techniques in 280 human patients. The difference in pain score after 2 weeks and 1,2 and 3 months was statistically significant in favor of the group sutured with transcostal sutures. YOON et al. (2015) proposed a muscle-sparing thoracotomy technique which achieved the desired exposure of the target organs. It was reported that the musclesparing thoracotomy resulted in less postoperative pain during the first 8 days of post-sugical period, providing a shorter pain management period and shorter hospital stays compared to a standard intercostal thoracotomy.

Surgical techniques which do not incorporate the intercostal nerve and cause severe post-thoracotomy pain during thoracotomy closure are being explored (PAVLIDOU et al., 2009). The transcostal suture technique is a method which employs rib drilling but does not incorporate the intercostal nerve into the suture (HUNT, 2012). We have not been able to find a research paper which compares mechanical strength between the different types of suture techniques used for intercostal thoracotomy closure.

The peak maximal forces at which suture rupture or rib fracture occurred barely differ between the groups. Therefore, the choice of closure technique regarding force tolerances is equal either way. It is not necessary to change the closure technique as the animal's body mass increases. Also, the transcostal technique is inappropriate for very small animals as the ribs are quite subtle, and drilling can cause the rib to fracture. In our opinion, this necessitates a circumcostal closure technique, as the risk of rib fracture makes the transcostal technique prohibitively risky.

In our research, the mean time needed for suturing in the different suture groups differed considerably. As expected, the closure with the continuous circumcostal suturing technique was the quickest, because there are fewer knots to tie, and the technique itself does not necessitate suture prepositioning. Likewise, the most time-consuming 
technique was the interrupted transcostal suture, since it first employs rib drilling, suture prepositioning and finally knot tying of each individual suture. Regarding surgical material used, the least amount of material was used by the continuous circumcostal suture. This result is obvious since the other two techniques use interrupted sutures. When performing interrupted sutures, it is advised to first pass the suture threads around the ribs and secure them with hemostatic forceps, and tie the knots afterwards. This way, a large amount of suture material is wasted. The peak force at which suture rupture or rib fracture occurred did not vary significantly between the animal groups. Therefore, we can say that all three techniques are equally solid for intercostal thoracotomy suturing. Significant differences were observed between the continuous circumcostal group and the other two groups (interrupted transcostal and interrupted circumcostal) in relation to the time required for suturing and suture material consumption. Continuous circumcostal suturing took the least amount of time, with the least amount of suture material used. Rib fracture and suture rupture occurence did not differ significantly between the different test groups $(\mathrm{P}>0.05)$. In the transcostal suture group, however, rib fracture occurrence was highest, at $70 \%$, while suture rupture was $30 \%$. The larger number of rib fractures in this group may be associated with rib pre-drilling, weakening the ribs.

The importance of suture strength is associated with thoracotomy wound dehiscence, a severe complication in human patients (NADIR et al., 2013). In a report by MOORES et al. (2007), long-term complications of thoracotomy in dogs and cats were rare. The surgical approach has a low complication rate, similar to general surgical complications. A rib fracture in one patient in their study may have occurred because of excessive rib retraction or following wound closure, but it did not require treatment.

The limitations of this study are the cadaver specimens and the small number of samples. If the suture material was implanted for a few days, the possibility of suture weakening would occur, as it would be partially absorbed by the tissue. Therefore, future work is needed to research the in vivo influence of suture absorption on mechanical wound strength after intercostal thoracotomy closure.

The conclusion of this paper would be that the continuous pattern suture has the same mechanical strength as the other two suture patterns, but it consumes less time and suture material. Therefore, we would advise the use of continuous transcostal suture for intercostal thoracotomy closure, but only after research on suture absorption on mechanical wound strength in an intercostal thoracotomy closure.

The results of this study show that the transcostal continuous sample group withstood the lowest force before rib breakage. This result reflects the fact the drilled ribs are more prone to breaking, as the drilled holes provide a stress riser and facilitate rib fracture.

\section{References}

CERFOlio, R. J., T. N. PRICE, A. S. BRYSNT, C. SALE BASS, A. A.BARTOLUCCI (2003): Intracostal sutures decrease the pain of thoracotomy. Ann. of Thorac. Surg. 76, 407-411.

DOI: $10.1016 / \mathrm{S} 0003-4975(03) 00447-8$

CONZEMIUS, M. G., D. J. BROCKMAN, L. G. KING, S. Z. PERKOWSKI (1994): Analgesia in dogs after intercostal thoracotomy: a clinical trial comparing intravenous buprenorphine and interpleural bupivacaine. Vet. Surg. 23, 291-298.

DOI: 10.1111/j.1532-950X.1994.tb00487.x

GARCIA-TIRADO, J., C. RIEGER-REYES (2012): Suture techniques of the intercostal space and their relationship with post-thoracotomy pain: a systematic review. Arch. Bronconeumol. 48, 22-28.

DOI: 10.1016/j.arbr.2011.04.011

HOLTON, L. L., E. M. SCOTT, A. M. NOLAN, J. REID, E. WELSH (1998): Relationship between physiological factors and clinical pain in dogs scored using a numerical rating scale. J. Small Anim. Pract. 39, 469-474.

DOI: 10.1111/j.1748-5827.1998.tb03681.x

HUNT, G.B. (2012): Thoracic wall. In: Veterinary Surgery Small Animal (Tobias K. M., S. A. Johnston, Eds.), $1^{\text {st }}$ ed., Saunders Elsevier, St. Louis, Missouri, pp. 1769-1786.

LÓPEZ, A. (2007): Respiratory System. In: Pathologic Basis of Veterinary Disease. $4^{\text {th }}$ ed. (McGavin, M. D., J. F. Zachary, Eds). Elsevier, pp. 463-558.

MERSKEY, H., N. BOGDUK (1994): Clasification of Chronic Pain Syndromes and Definitions of Pain Terms, $2^{\text {nd }}$ ed., IASP. 
MOORES, A. L., Z. J. HALFACREE, S. J. BAINES, V. J. LIPSCOMB (2007): Indications, outcomes and complications follloving lateral thoracotomy in dogs and cats. J. Small Anim. Pract. 48, 695-698.

DOI: $10.1111 / \mathrm{j} .1748-5827.2007 .00417 . \mathrm{x}$

MOSCARELLI, M., P. P. PUNJABI (2011): Thoracotomy. Surg. 29, 242-243.

DOI: 10.1016/j.mpsur.2011.02.008

NADIR, A., M. KAPTANOGLU, E. SAHIN, H. SARZEP H. (2013): Post-thoracotomy wound separation (DEHISCENCE): a disturbing complication. Clinics (Sao Paulo); 68, 1-4.

DOI: 10.6061/clinics/2013(01)OA01

ORTON, E.C. (2003): Thoracic wall. In: Textbook of Small Animal Surgery, $3^{\text {th }}$ ed. (Slatter, D. H., Ed.) Saunders Elsevier, Philadelphia, pp. 373-787.
PAVLIDOU, K., L. PAPAZOGLOU, I. SAVVAS, G. KAZAKOS (2009): Analgesia for small animal thoracic surgery. Compend. Contin. Educ. Vet. 31, 432-436.

RADLINSKY, M. A. G. (2012): Thoracic cavity. In: Veterinary Surgery Small Animal. (Tobias K. M., S. A. Johnston, Eds.), Saunders Elsevier, St. Louis, Missouri, pp. 17871812.

ROONEY, M. B., M. MEHL, E. MONNET (2004): Intercostal thoracotomy closure:transcostal sutures as a less painful alternative to circumcostal suture placement. Vet. Surg. 33, 209-213.

DOI: 10.1111/j.1532-950X.2004.04031.x

YOON, H. Y., S. LEE, S. W. JEONG (2015): Intercostal thoracotomy in 20 dogs: musle-sparing versus traditional tehnique. J. Vet. Sci. 16, 93-98.

DOI: $10.4142 /$ jvs.2015.16.1.93

Received: 22 December 2017

Accepted: 6 July 2020

KOSTEŠIĆ, P., M. VUČKOVIĆ, J. KODVANJ, M. ŠURJAK, D. VNUK, N. DARABOŠ, D. MATIČIĆ: Usporedba mehaničke čvrstoće triju različitih tehnika šivanja za zatvaranje interkostalne torakotomije istraživanje ex vivo. Vet. arhiv 90, 637-642, 2020.

\section{SAŽETAK}

Doima se da je interkostalna tehnika zatvaranja torakotomije povezana s manje bola unutar prva 24 sata te bi mogla bi biti alternativa standardnoj cirkumkostalnoj tehnici. Cilj ovog istraživanja bio je usporediti ex vivo biomehanička svojstva triju tehnika za zatvaranje interkostalne torakotomije. Za istraživanje su korišteni uzorci svinjskih rebara. Na svakom je uzorku učinjena incizija duga $10 \mathrm{~cm}$. Uspoređivano je jednostavno cirkumkostalno pojedinačno šivanje, produžno cirkumkostalno šivanje i pojedinačno transkostalno šivanje. Tijekom testiranja na trgalici popuštali su šavovi ili je došlo do loma rebara. Ako je došlo do loma rebara, testiranje je nastavljeno do popuštanja šavova. U prvoj skupini lom rebara dogodio se na $60 \%$ uzoraka, dok je u $40 \%$ uzoraka popustio šivaći materijal. U drugoj skupini u $55 \%$ uzoraka popustila su rebra, dok je u $45 \%$ uzoraka popustio šivaći materijal. U trećoj skupini u $70 \%$ uzoraka popustila su rebra, dok je u $30 \%$ slučajeva popustio šivaći materijal. Ovi se podaci ne razlikuju znakovito među testiranim skupinama $(P>0,05)$. Produžnim cirkumkostalnim šivanjem utrošak vremena bio je najmanji, dok je pojedinačnim transkostalnim šivanjem utrošak vremena bio najveći. Jednostavnim cirkumkostalnim šivanjem utrošilo se najviše šivaćeg materijala, dok je najmanje materijala utrošeno produžnim cirkumkostalnim šivanjem. Zaključak ovog rada je da produžno šivanje pruža jednaku mehaničku snagu kao i ostale testirane metode, ali je utrošak vremena i materijala manji. Stoga, s mehaničkog stajališta, za zatvaranje interkostalne torakotomije preporučujemo jednostavni cirkumkostalni šav.

Ključne riječi: torakotomija; zatvaranje; tehnike; rebra; snaga; svinje 